\title{
Coronavirus (COVID-19): Exploring the Unprecedented Challenges and Possibilities
}

\author{
Morvyn N. Nyakudya ${ }^{1}$, Unity N. Nyakudya ${ }^{2}$, Ruramayi Tadu${ }^{1}$, Lovemore Thusabantu ${ }^{1}$ \\ ${ }^{1}$ BA ISAGO University, Gaborone, Botswana \\ ${ }^{2}$ Botswana Accountancy College, Gaborone, Botswana \\ Email: morvyn.nyakudya@baisago.ac.bw, ruramayi.tadu@baisago.ac.bw, lovemore.thusabantu@baisago.ac.bw
}

How to cite this paper: Nyakudya, M. N., Nyakudya, U. N., Tadu, R., \& Thusabantu, L. (2020). Coronavirus (COVID-19): Exploring the Unprecedented Challenges and Possibilities. Open Journal of Social Sciences, 8 , 377-398.

https://doi.org/10.4236/jss.2020.89029

Received: August 4, 2020

Accepted: September 26, 2020

Published: September 29, 2020

Copyright $\odot 2020$ by author(s) and Scientific Research Publishing Inc. This work is licensed under the Creative Commons Attribution International License (CC BY 4.0).

http://creativecommons.org/licenses/by/4.0/

\begin{abstract}
It appears that the coronavirus disease has brought far reaching life and economic consequences across the globe. This disease has rapidly spread throughout the world ravaging the lives of people and economies with impunity. In attempts to control its spread, different countries embarked on lengthy lockdowns in which their economies virtually ground to a halt due to employees' incapacity as a result of extreme illness or death. As the lockdowns are being eased to resuscitate the countries' economies, there is a high likelihood of massive reductions in sales revenue, jobs and income as well as a sharp increase in innovative ways of transacting in business including online platforms. This is envisaged to affect all countries including Botswana. This study explores the several and often rapid transformations that businesses are likely to experience in the post-COVID-19 era. The findings are still unfolding but the obvious ones are: jobs are being cut; sales revenues are reducing due to non-productivity; there is a rapid proliferation of online platforms used by especially workers and students; companies are cutting salaries and countries are introducing initiatives to address the challenges presented by COVID-19 such as, among others, cash transfers; wage subsidies; in-kind food/vouchers schemes and unemployment benefit.
\end{abstract}

\section{Keywords}

COVID-19, Coronavirus, Botswana, Lockdown

\section{Introduction}

A new virus known as the coronavirus which causes COVID-19 was discovered on 31 December 2019. It erupted in the town of Wuhan in China. In no time, it had spread to the whole of Asia, Europe, the Americas, Africa and Australia/New Zealand. The World Health Organization termed the disease a pandemic 
after noticing that it was now consuming nations and causing unprecedented disruption to the economic and social wellbeing of countries. The study aims to identify if there are any tangible possibilities after COVID-19 given the magnitude of the distress it has caused.

\section{BACKGROUND}

The statistics on COVID-19 are changing rapidly. For the purpose of this paper and the fact that the infection and death rates are falling, the figures quoted herewith are for the period up to 16 July 2020 and can be treated as a good approximation of what is yet to come. The whole thing started in Wuhan which became known as the epicenter of the virus. By 16 July 2020, the total number of confirmed cases worldwide had reached 13.6 million with a death toll of 585 thousand people. The USA is leading with 3.53 million confirmed infections and 138 thousand deaths. In Botswana, there are 422 confirmed cases and only one death.

During the disease's rapid spread, Europe (particularly Italy, Spain, France, Russia and the United Kingdom) took the baton from Wuhan, followed by the United States of America (USA) which has so far been the worst affected country. South America has seen the largest figures in Brazil, Peru, Chile and Mexico.

In Africa, the number of confirmed infections has reached 644,205 with 14,044 deaths. According to the John Hopkins University and Africa Center for Disease Control on COVID-19 in Africa, some of the most impacted nations are:

- South Africa: $311 \mathrm{~K}$ confirmed cases;

- Egypt: 85K;

- Algeria: $21 \mathrm{~K}$

- Morocco: 16.5K;

- Nigeria: $34 \mathrm{~K}(\mathrm{~K}=1000)$.

The latest numbers for some selected countries, including Botswana, are depicted in Table 1; this data is on 16 July 2020, according to the World Health Organisation (WHO, 2020).

The pandemic has caused Governments to react by imposing a range of prevention and containment measures against the spread of the disease. These measures include mandatory lockdowns where all people, including the productive ones, were expected to stay at home. People generally abided by the arrangement and stayed at home. The lockdowns however had their own problems some of which were the complete meltdown of the countries' economies as well as the eroding away of the social wellbeing of human beings. Factories and service centers were closed down resulting in no production which in turn resulted in the loss of, among others, revenues and jobs. As lockdowns are now being eased worldwide based on the countries' preparedness as recommended by the World Health Organization, it is time to count the costs and to assess whether it will be business as usual or there is a new status quo altogether. This study first traverses the effects of the pandemic as expounded in very current literature. It then explores through the possibilities after the pandemic. 
Table 1. World Health Organisation (WHO, 2020) data as on 16 July 2020.

\begin{tabular}{|c|c|c|c|c|}
\hline Place & & Confirmed & Deaths & \\
\hline World & & 13.6 million & $585 \mathrm{~K}$ & \\
\hline \multirow[t]{4}{*}{ Africa } & Botswana & 422 & 1 & $\begin{array}{l}\text { Botswana and most } \\
\text { African Countries has } \\
\text { reported low numbers }\end{array}$ \\
\hline & South Africa & $311 \mathrm{~K}$ & 4453 & \\
\hline & Egypt & $85 \mathrm{~K}$ & $4 \mathrm{~K}$ & \\
\hline & Algeria & $21 \mathrm{~K}$ & $1 \mathrm{~K}$ & \\
\hline \multirow[t]{6}{*}{ Americas } & United States & 3.53 million & $136 \mathrm{~K}$ & \\
\hline & Brazil & 1.97 million & $75 \mathrm{~K}$ & \\
\hline & Bolivia & $51 \mathrm{~K}$ & $2 \mathrm{~K}$ & \\
\hline & Peru & $338 \mathrm{~K}$ & $13 \mathrm{~K}$ & \\
\hline & Chile & $321 \mathrm{~K}$ & $7 \mathrm{~K}$ & \\
\hline & Mexico & $318 \mathrm{~K}$ & $40 \mathrm{~K}$ & \\
\hline \multirow[t]{7}{*}{ Europe } & United Kingdom & $292 \mathrm{~K}$ & $45 \mathrm{~K}$ & \\
\hline & Spain & $257 \mathrm{~K}$ & $29 \mathrm{~K}$ & \\
\hline & Italy & $244 \mathrm{~K}$ & $35 \mathrm{~K}$ & \\
\hline & Russia & $753 \mathrm{~K}$ & $12 \mathrm{~K}$ & \\
\hline & Germany & $201 \mathrm{~K}$ & $9 \mathrm{~K}$ & \\
\hline & France & $17 \mathrm{~K}$ & $30 \mathrm{~K}$ & \\
\hline & Turkey & $216 \mathrm{~K}$ & $6 \mathrm{~K}$ & \\
\hline Asia & India & $969 \mathrm{~K}$ & $25 \mathrm{~K}$ & \\
\hline
\end{tabular}

Source: World Health Organisation, 2020.

\section{OBJECTIVES}

The major objective of this paper is to explore the economic and social possibilities after COVID-19. This will be done through fulfilling both literature and empirical objectives. This study is premised on the following specific objectives.

1) To assess the effects of COVID-19 worldwide.

2) To explore the economic stimulus packages put in place by nations to address the COVID-19 challenges.

3) To evaluate Botswana's contribution in addressing COVID-19 challenges.

In line with these objectives, research questions are paused.

\section{RESEARCH QUESTIONS}

1) What are the effects of COVID-19 worldwide?

2) Which economic stimulus packages are nations putting in place in order to address the COVID-19 challenges?

3) What is Botswana's contribution to addressing COVID-19 challenges?

\section{Literature Review}

The COVID-19 pandemic has caused immeasurable damages to human and 
economic lives with consequences such as, among others, job losses, pay cuts, revenue drops and changes in work styles. It is evident that if employees are not actively and physically engaged at their workplaces, there is high likelihood of getting proportionally reduced salaries and revenues for companies. In worst cases, employees will have to be retrenched leading to zero production and hence zero revenue. If salaries are not reduced, they can actually be cancelled altogether for the time not worked. Some companies take this opportunity to reduce their labor force. When such times come, people ordinarily suffer huge consequences and this calls for interventions of any kind especially by Government so that decent living is maintained.

\section{JOB LOSSES}

According to the International Labor Organization (2020), the so-called full or partial lockdowns are projected to have a negative effect on 2.7 billion workers worldwide. This is $81 \%$ of the total workforce in the world. Small and medium enterprises (SMEs) were particularly affected more than the larger firms with a projected loss of millions of jobs. Again ILO (2020) indicates that the informal sector will be hit hard.

Apart from losing their jobs, ILO (2020) also notes the changes that are likely to take place in the work environments. Of particular interest are changes in working hours where workers can work fewer hours and practice shift work, changes in working platforms-working from home by setting up virtual offices for most essential workers while the rest are idle. Software platforms became very popular during the countries' mandatory lockdowns where teaching; church services and meetings for essential workers were conducted using information and communication technology applications. These applications saw a huge uptake as organisations and consumers were afraid to lose a whole year (2020) while closed away through lockdowns. The technology platforms included the Zoom, Google Meet and Teams to mention a few.

Zoom allows you to hold meetings using video, audio or both. Business and office meeting normally are done effectively through the Google Meet which allows users to perform chats over video and text. Microsoft Teams allows collaboration with document sharing, online meetings, and many more extremely useful features for business communications.

As a result of this set up, organizations will not make any viable profits and hence salaries will be reduced drastically or cancelled altogether resulting in workers losing their jobs. For as long as the pandemic is not controlled or stopped completely, job losses will be many and the counting will only continue until the end of 2020. ILO (2020) notes that the counting exercise is conducted per day, per week and per month adding that the job losses are not stopping.

ILO (2020) projections indicate that 1.25 billion workers who will lose their jobs are those in the retail, trade, accommodation, airline, manufacturing and food services sectors adding that this figure accounts for $38 \%$ of the global workforce. Accommodation and food industries are labor intensive sectors which require workers all the time but due to lockdowns, the workers stayed 
away from work resulting in factories closing which in turn rendered global supply chains defunct. These sectors account for over 500 million employees. The transport/storage/communication sector has a total of over 204 million including, among others, pilots, crew members, drivers, postal, delivery work and warehousing staff. Because of food deliveries to homes under lockdown, the agriculture sector is still viable although there is so much demand which is not complemented by supply since those who work in the sector are also incapacitated due to lockdown. Those delivering the food are not replenishing the source.

Apart from falling into deep poverty and ill health due to lack of medical aid, the majority of those in the informal sector will also fail to sustain their insurances. Over 2 billion jobs will be lost especially in emerging and developing economies. The informal sector whose major players are, among others, street vendors, food servers, construction, transport and domestic workers do not enjoy social protection since they do not usually insure their operations. In India, Brazil and Nigeria for instance, $90 \%$ of the informal sector workers will lose their jobs and salaries and eventually will settle in the rural areas. This whole scenario calls for Governments all over the world to put in place policy responses needed to protect the vulnerable as well as businesses. Particularly, these policies should focus on immediate relief to workers and enterprises. ILO (2020) emphasizes on the need to have policy responses which address the four pillars, namely:

1) Stimulating the economy and employment;

2) Supporting enterprises, jobs and incomes;

3) Protecting workers in the workplace;

4) Relying on social dialogue for solutions.

In considering these four pillars, there is strong need to especially consider the plight of the informal sector by supporting workers and enterprises.

It is common knowledge that public resources in developing countries are limited. As such, countries are encouraged to advise those responsible for distribution to use these resources responsibly and sensibly so as to create or retain jobs. Currently, there is a rush to make face masks, Personal Protective Equipment (PPE) kits (gloves, mask, gown, face protection shields, goggles, coveralls, head cover, rubber boots, etc.) to protect health care workers. Others have created companies to deliver food supplies to homes while some have engaged in fumigation of establishments at a fee. The downside though is that, for these companies to start operating, they have to apply for operating licenses which usually take time to be ready due to the bureaucratic nature of Government offices regarding the way they work.

As of 29 May 2020, the pandemic has infected 5.8 million with 2.4 million recoveries while 360 thousand people have succumbed to death. These numbers are rising, a research on similar concepts, and carried out a month from now, will certainly have different figures. Lockdowns will ensure that social distancing is adhered to, schools and universities will close and manufacturing will drop since many workers are not physically at their workstations. This situation has 
ripple effects on many facets including mandatory or recommended work closure, reduction in economic activity which will result in a drastic reduction in employment.

ILO (2020) has stated that the COVID 19 pandemic is the most severe crisis since the Second World War with employment losses arising rapidly around the world. Some statistics are shown in Table 2.

From Table 2, it is clear that Africa faces huge financial difficulties as capital outlays in such transactions as utility and financial obligation support (waiver/postponement), social security contributions subsidy/waiver and one-off payments are not very significant.

Bouey (2020) discusses the ongoing epidemic and various travel bans and states that workers will temporarily or permanently be laid off. Bouey also cautions organizations on the difficulties they will face in acquiring re-opening permits resulting in no production and loss of jobs. Further, Bouey laments the impact on the economy noting that the longer the SMEs take to reopen, the more the unemployment rate, the lower the demand and hence the lower the sales figures. Multiple industries exist in Wuhan and Hubei province, the epicenter of the COVID-19. A chain reaction affecting the automotive, electrical and ship building industries will therefore result in many job losses. Bouey writes that only $30 \%$ of the workforce in this vast industrial territory was at work as at end of February 2020. However, because of the zeal to keep industry going, a cash injection of $\$ 114.2$ billion was made available for small businesses. But a prolonged epidemic will result in the shrinking of market demands leading to laying off of workers to balance the lack of revenue. And if revenue reduces, demand will reduce further.

The World Bank (2020) report on East Asia and Pacific has predicted layoffs

Table 2. Crisis is leading to a severe decline in working hours and employment.

\begin{tabular}{cccc}
\hline & $\begin{array}{c}\text { Decline in working } \\
\text { hours (\%) }\end{array}$ & $\begin{array}{c}\text { Full-time equivalent } \\
\text { (48 hours, million) }\end{array}$ & $\begin{array}{c}\text { Full-time equivalent } \\
\text { (40 hours, million) }\end{array}$ \\
\hline World & 6.7 & 230 & 195 \\
Low income & 5.3 & 14 & 12 \\
Lower-middle income & 6.7 & 80 & 70 \\
Upper-middle income & 7.0 & 100 & 85 \\
High income & 6.5 & 36 & 30 \\
Africa & 4.9 & 22 & 19 \\
Americas & 6.3 & 29 & 24 \\
Arab States & 8.1 & 6 & 5 \\
Asia and the Pacific & 7.2 & 150 & 125 \\
Europe and Central Asia & 6.0 & 24 & 20 \\
(Europe) & 7.8 & 15 & 12 \\
\hline
\end{tabular}

Source: ILO Monitor: COVID-19 and the world of work 2020. 
in the garment manufacturing sector totaling to over 500 thousand. Usually, poor household individuals migrate to temporary low-paid jobs but because of the lockdowns, this has stopped. The Pacific Islands of Fiji, Samoa, Tonga where tourism is the major sector (hotels, airlines, transport, agriculture and construction) jobs have been lost. In the USA, 28.6 million workers have also lost their jobs. This constitutes a quarter of the USA workforce.

The United Nations (UN) (2020) promulgates the issue of retrenchment noting that if the economy falls into prolonged lockdowns, there will be a total shutdown of production which will ordinarily lead to the retrenchment of employees. As a result, the global and country unemployment rates will rise. Many options have been muted: from end of March 2020, employees can be sacked, or they can be asked to go on leave or they can continue to be engaged on reduced salaries. All this information is being transmitted by Chief Executive Officers (CEOs) to their employees. The UN has predicted massive disruptions of this nature in Agriculture and Real Estate. Shrivastava (2020) paints a fitting piece based on pay cuts, layoffs and lockdowns noting that Indian employees had already been fired by 25 April 2020. At least 2 dozen top companies had already fired all their employees despite the fact that they had been promised that their contracts would not be cut. Shrivastava's argument is based on the fact that top companies such as Oyo, BlackBuck, BharatPe, Acko, Fab Hotels, Zolo Slays, Treebo, Udaan, 19Springboard, Grofers and Homelane had already put employees on forced extended leave. According to Arunmas (2020), tourism supply chains are most affected by the outbreak and unemployment is at its all time low. Arunmas projects a future where the current country lockdowns would cause a loss of 7 million jobs by June 2020 as well as workers who are lowly paid. In total, 4.2 million retail and shopping mall workers, 1 million in construction, 978,000 hotel workers, 250,000 in restaurants, 200,000 in spa and massage sectors and another 200,000 in garments factory will either lose their jobs or have their wages reduced. Kar (2020) singles out software engineers, project managers, sales, marketing, operations personnel as the most affected.

Nayar, Sood, Kansara, and Ahmand (2020) have observed that from the end of March 2020, companies will sack and send employees on indefinite leave or on slashed salaries with CEOs as the main carrier of the messages of doom. According to Shrivastava (2020), Bounce, Liyspace, AgroStar, BookMyShow and Droom have cut salaries by between 15\% and 70\%. Arunmas (2020) argues that, due to paycuts, consumers are not buying much and this is triggered by dwindling salaries.

As the pandemic continues to ravage the world, the World Economic Forum (WEF) in collaboration with the US Bureau of Labor Statistics (2020) has highlighted some shocking statistics to the effect that: 1) by April 2020, 14.7\% rate of unemployment would have been recorded in April, 2) 42\% of pandemic induced job losses may actually be permanent, 3) long term consequences will be felt long after the containment of the virus and 4) some companies are now being creative by using the swap and exchange tactics where grocery chains are 
pairing with hotels and retail stores are working closely with gig companies.

\section{REVENUE LOSSES}

During this pandemic, jobs will be lost resulting in little production. When this happens, revenues will also drop. The 2020 ILO report states sectors are facing catastrophic losses especially smaller enterprises because of their usually poor cash flows. In the informal sector economy, where players do not have collateral, Government or any protection is not possible. As a result, these sectors will close down resulting in severely dwindled sales volumes. This will lead to non-existent revenue. The largest fall in revenues is bound to be felt in the accommodation and food services. Economic hardships will ensue as the workers who remain will have huge pay cuts that will negatively affect their morale and motivation. The most discouraging sentiment by ILO (2020) is that accommodation and food services, where half of the workforce is are women, could face full closure. This will mean that there will be no sales, because orders have been cancelled which in turn will result in zero revenues. Zero revenue will mean no salaries and with no pay, poverty will be rampant.

Bouey (2020) foresees low market demand due to lockdowns. Lockdowns will have the effect of low revenues and poor cash flows. The loss in the first quarter of 2020 has been termed a natural disaster. In China, with 7 out of the 9 busiest ports in the world, the shipping volumes have fallen drastically with the economy losing \$350 million per week. Slow movement of goods is now the order of time whether by air, road or rail. As a result, goods remain piled up at ports. When this happens, revenues will certainly fall. Bouey has also reported that inbound container volumes at US seaports are projected to be down $12.9 \%$ in February and 9.5\% in March as compared to February and March of 2019.

In a World Bank Report of 2020, a huge drop in external demands is anticipated because of contraction in tourism revenues in Cambodia, Lao PDR, Malaysia, Pacific Islands, Philippines and Thailand (2020 Global Economic Prospects Report).

Tourism revenue in Victoria Falls in Zimbabwe is virtually non-existent since the beginning of 2020. Pilots are grounded 2020-no visits are allowed to watch the water falls, no flights are allowed to depart from and to land at Victoria Falls Airport while accessing the various tourist destinations like Hwange National Park, Mana Pools, Kariba Dam and other places of and there is virtually no revenue realization at Wilderness Zimbabwe.

The IMF, World Economic Outlook of April 2020 presents growth projections noting that the COVID-19 pandemic will severely impact growth across all regions. Figure 1 presents two groups: advanced economies (USA, European countries such as Germany, France, Italy and Spain, Japan, the United Kingdom and Canada) as well as emerging markets and developing economies (including China and India). Almost all countries predict negative growths outlooks in 2020 and will start to pick up in 2021.

\section{PAY CUTS}




\section{Latest World Economic Outlook Growth Projections}

\begin{tabular}{|c|c|c|c|}
\hline \multicolumn{2}{|l|}{$\begin{array}{l}\text { The COVID-19 pandemic will severely impact } \\
\text { growth across all regions. }\end{array}$} & \multicolumn{2}{|c|}{ PROJECTIONS } \\
\hline & 2019 & 2020 & 2021 \\
\hline World Output & 2.9 & -3.0 & 5.8 \\
\hline Advanced Economies & 1.7 & -6.1 & 4.5 \\
\hline United States & 2.3 & -5.9 & 4.7 \\
\hline Euro Area & 1.2 & -7.5 & 4.7 \\
\hline Germany & 0.6 & -7.0 & 5.2 \\
\hline France & 1.3 & -7.2 & 4.5 \\
\hline Italy & 0.3 & -9.1 & 4.8 \\
\hline Spain & 2.0 & -8.0 & 4.3 \\
\hline Japan & 0.7 & -5.2 & 3.0 \\
\hline United Kingdom & 1.4 & -6.5 & 4.0 \\
\hline Canada & 1.6 & -6.2 & 4.2 \\
\hline Other Advanced Economies & 1.7 & -4.6 & 4.5 \\
\hline Emerging Markets and Developing Economies & 3.7 & -1.0 & 6.6 \\
\hline Emerging and Developing Asia & 5.5 & 1.0 & 8.5 \\
\hline China & 6.1 & 1.2 & 9.2 \\
\hline India & 4.2 & 1.9 & 7.4 \\
\hline ASEAN-5 & 4.8 & -0.6 & 7.8 \\
\hline Emerging and Developing Europe & 2.1 & -5.2 & 4.2 \\
\hline Russia & 1.3 & -5.5 & 3.5 \\
\hline Latin America and the Caribbean & 0.1 & -5.2 & 3.4 \\
\hline Brazil & 1.1 & -5.3 & 2.9 \\
\hline Mexico & -0.1 & -6.6 & 3.0 \\
\hline Middle East and Central Asia & 1.2 & -2.8 & 4.0 \\
\hline Saudi Arabia & 0.3 & -2.3 & 2.9 \\
\hline Sub-Saharan Africa & 3.1 & -1.6 & 4.1 \\
\hline Nigeria & 2.2 & -3.4 & 2.4 \\
\hline South Africa & 0.2 & -5.8 & 4.0 \\
\hline Low-Income Developing Countries & 5.1 & 0.4 & 5.6 \\
\hline Sourco: IMF, World Economic Outlook, April 2020 & & & \\
\hline $\begin{array}{l}\text { tia, data and forecasts are presented on a fiscal year } \\
\text { oril } 2020 \text {. India's growth is } 0.5 \text { percent in } 2020 \text { basec }\end{array}$ & with & & \\
\hline
\end{tabular}

Figure 1. IMF, World Economic Outlook, April 2020.

Companies have the obligation to provide salaries for their workers. Yet sectors are folding up and stopping operations due to the COVID-19 pandemic. Once operations have stopped, production will fall, there will be less demand and so workers are bound to lose their right to get paid. At best they may get reduced pay. According to ILO (2020), "these workers are facing a drastic and devastating reduction in working hours, wage cuts and layoffs (p. 5). Cancellation of orders is being felt in manufacturing, food and accommodation and hence no salaries are due for any task done because those tasks are non-existent. Other sectors that are facing dented salaries include auto, textiles, clothing, leather and footwear. Low wage employees will lose that little salary or, even if they retain it. It will not be adequate to cover their social protection. It will be difficult therefore to access insurance and healthcare. Bouey (2020) also observes that small and medium enterprises, due to their low capacities to produce reasonable quantities in light of having retrenched their workers, will find it hard to pay full salaries: at best, they can pay a fraction only.

\section{CHANGES IN WORK STYLES}

For a long time, workers have always gathered in offices, production lines, service stations and other such places to deliver their organizations' mandate 
through working under supervision. This physical presence is likely to stop post-COVID-19 where social distance is strictly observed. For the few weeks that this researcher was abiding by the country lockdown rules, several meetings of Deans, Faculties and Executive Management were held. Some institutions, Botho University in particular, offered a free online course on how to teach using online systems. Association of African Universities presented their programme from Ghana which reached several scores of Lecturers. Botswana Accountancy College met its staff virtually using Teams platform. Bouey (2020) presents the idea of working from home using online platforms. Bouey states that, to effectively address the challenges posed by COVID-19, China summoned its prowess in e-commerce, online education and remote working. China has developed its Internet connectivity and electronics to a level that permits easy and quick access to information and data. Lin (2020) notes that “... China's cities, with their empty streets and deserted malls, were able to access food supplies, medical services and salaries" using digital technologies. Wuhan, with a population of 11 million used digitally enabled systems to deliver food to households in less than 20 minutes. Households were visited while sitting comfortably in their homes. In this regard, essential services and goods were able to reach those under self-quarantine or lockdown. Lin emphasizes that, because of the complications brought about by the emergency of COVID-19, China enjoyed its "digital advantages" over USA and Europe. China was even ready for "next" pandemic as they would be found ready.

Home working is not a habit for many but now workers are meeting virtually using such platforms as Teams and Zoom. Shetty (2020) advocated for people to work from home so that they address the aspect of social distancing and presented several information technology (IT) platforms to use. People under quarantine employ mobile applications to transfer funds.

The Coronavirus has forced Universities, colleges and schools to close leading to total disruption of the syllabuses. These establishments were closed as a precautionary measure arguing that this move would slow down the spread of the pandemic. In this regard, Bao (2020) showcases Peking University in China which, during this period, has abandoned the traditional in-class "face-to-face to online education". Fortunately, China had started vigorously to pursue the online-learning route well below the outbreak. By March 2020, 61 countries in Africa, Asia, Europe, the Middle East, North America and South America had closed schools (UNESCO, 2020). By 2017, China had developed over 500 Massive Open Access Courses (MOAC) and this proved advantageous for Peking University which was forced to launch 2613 undergraduate and 1824 postgraduate courses online. The new normal has changed from face-to-face teaching to a more convenient method in the circumstances that the world sees itself in. UNESCO (2020) notes that the institution of nationwide lockdowns by countries would impact $70 \%$ of the world's student population. UNESCO then advises the relevant authorities to introduce distance learning aimed at targeting those students who are at risk as well as employing WEBNARS for education authorities to share information. 
Remote working has increased and UNESCO (2020) puts the increase at 261\% with Shrivastava (2020) noting that technology startups will cut more jobs in retail, hospitality, mobility and financial services.

\section{COUNTRIES' INITIATIVES}

COVID-19 has brought immeasurable hardships and Governments across the globe have put in place measures that include, among others, cash transfers, wage subsidy, in-kind food/vouchers schemes, unemployment benefit and social pension. United Nations (2020) suggests stabilization packages to "flatten both curves of the pandemic and that of economic meltdown" through, among others, cash transfers, credit lines and Governments guarantee meant to cover households and firms. Coordinating with many other contributors, Gentilini, Almenfi, and Dale (2020) presents these and other measures. Adapted from a tabular representation by Gentilini, Almenfi, and Dale (2020), Tables 3-6 depict some countries' initiatives that are meant to help their populations in maintaining their standards of living.

Table 3. Cash transfer.

\begin{tabular}{|c|c|}
\hline Country & Descriptive Summary \\
\hline Spain & $\begin{array}{l}\text { Among the measures to support families is to guarantee the basic right to food for } \\
\text { vulnerable children who are affected by school closures. Specifically, a total of Euro } \\
25 \mathrm{M} \text { is established to provide income support (wallet cards, wire transfer, voucher in } \\
\text { supermarkets). }\end{array}$ \\
\hline South Korea & $\begin{array}{l}\text { W200B to low-income households getting unemployed and to those under } \\
\text { COVID- } 19 \text { treatment/quarantine. } \\
\text { Reintroduction of job seekers' allowance for low-income households, with such } \\
\text { allowance being increased from W200,000 to 500,000 for up to } 3 \text { months. } \\
\text { The government decided to offer emergency relief payments of } 9.1 \text { trillion won to } \\
\text { households in the bottom } 70 \text { percent income bracket. A total of } 14 \text { million } \\
\text { households to become recipients. Payments to vary according to the household } \\
\text { members: } 0.4 \text { million won (single-person households), } 0.6 \text { million won (two-person } \\
\text { households), } 0.8 \text { million won (three-person households), } 1.0 \text { million won } \\
\text { (four-person households). }\end{array}$ \\
\hline Singapore & $\begin{array}{l}\text { The new (second) stimulus package of } \$ \$ 48 \text { billion ( } \$ 33 \text { billion) includes cash } \\
\text { transfers to self-employed and low-income people. }\end{array}$ \\
\hline UK & $\begin{array}{l}\text { The UK would raise its main state-paid benefit. The universal credit standard } \\
\text { allowance for the next } 12 \text { months would increase by } 1,000 \text { pounds a year, with the } \\
\text { working tax credit basic element rising by the same amount as well. It is expected } \\
\text { that the measures will benefit over } 4 \text { million of the most vulnerable households. } \\
\text { For the duration of the outbreak, the requirements of the Universal Credit Program } \\
\text { will be temporarily relaxed for those who have COVID-19 or are self-isolating } \\
\text { according to government advice. People will be able to claim Universal Credit and } \\
\text { access advance payments upfront without the current requirement to attend a job } \\
\text { Centre if they are advised to self-isolate. }\end{array}$ \\
\hline USA & $\begin{array}{l}\text { Adults will get } \$ 1200 \text { each and children } \$ 500 \text { each. The benefit will start decreasing } \\
\text { at a rate of } \$ 5 \text { for every additional } \$ 100 \text { in income. The phaseout starts at } \$ 75,000 \text { in } \\
\text { adjusted gross income for singles, } \$ 112,500 \text { for heads of household, and } \$ 150,000 \text { for } \\
\text { married couples filing jointly; it will phase out entirely by } \$ 99,000 \text { for singles and } \\
\$ 198,000 \text { for couples (with no children). }\end{array}$ \\
\hline
\end{tabular}

Source: Gentilini, Almenfi, and Dale (2020). 
Table 4. Wage subsidy.

\begin{tabular}{|c|c|}
\hline Country & Descriptive Summary \\
\hline Argentina & $\begin{array}{l}\text { See the Emergency Assistance Program for Work above. The allocation amount will } \\
\text { be determined according to the following parameters: } \\
\text { - For employers with up to } 25 \text { workers: } 100 \% \text { of the gross salary, with a maximum } \\
\text { value of } 1 \text { current Minimum Wage. } \\
\text { - For the employers of } 26 \text { - } 60 \text { workers: } 100 \% \text { of gross salary, with a maximum value } \\
\text { of up to } 75 \% \text { of the current Minimum Wage. } \\
\text { - For the employers of } 61-100: 100 \% \text { of gross salary, with a maximum value of up } \\
\text { to } 50 \% \text { of the current Minimum Wage. }\end{array}$ \\
\hline Australia & $\begin{array}{l}\text { Wage subsidy of } 50 \% \text { of the wage of apprentices and trainees from January to } \\
\text { September } 2020 \text {; the subsidy is up to AUD } 21,000 \text { per person and for a total cost of } \\
\text { AUD } 1.3 \text { billion. } \\
\text { Wage subsidy of up to A } \$ 1,500 \text { per employee per fortnight in Australia, including } \\
\text { casual and part time employees. }\end{array}$ \\
\hline $\begin{array}{l}\text { Bosnia and } \\
\text { Herzegovina }\end{array}$ & $\begin{array}{l}\text { A total of Eur } 5.5 \mathrm{M} \text { is allocated for unemployment benefits for 2020, but this could } \\
\text { increase to another Eur 10M to support job retention and/or increase unemployment } \\
\text { benefits. }\end{array}$ \\
\hline Denmark & $\begin{array}{l}\text { The Danish government would cover } 75 \% \text { of employees' salaries if firms committed } \\
\text { not to lay off workers. This program will last for three months, or until } 9 \text { June } 2020 \text {. } \\
\text { The subsidy will cover a maximum of } 23,000 \text { Danish krone/month ( } \$ 3418) \text {. }\end{array}$ \\
\hline Italy & $\begin{array}{l}\text { To discourage layoffs during the crisis, employees of companies that have } \\
\text { interrupted their activities will be entitled to receive a benefit in the amount of } 80 \% \\
\text { of the salary paid by the state. The measure would be valid for up to nine } \\
\text { weeks, and no longer than August } 2020 \text {. }\end{array}$ \\
\hline
\end{tabular}

Source: Gentilini, Almenfi, and Dale (2020).

Table 5. In-kind food/vouchers schemes.

\begin{tabular}{|c|c|}
\hline Country & Descriptive Summary \\
\hline Bulgaria & $\begin{array}{l}\text { Expanding the coverage and scope of the home visiting services provided to elderly } \\
\text { people and other vulnerable groups (people with disabilities), including the delivery } \\
\text { of food and medicines. }\end{array}$ \\
\hline Costa Rica & $\begin{array}{l}\text { Special food packages and sanitary items are delivered for families in extreme } \\
\text { poverty. }\end{array}$ \\
\hline Jordan & $\begin{array}{l}\text { In kind distribution of bread (universal) will occur at reduced subsidized price (JD1 } \\
\text { per } 3 \mathrm{~kg} \text {, instead of JD1.5). The Ministry of Local Affairs is coordinating distribution } \\
\text { from local bakeries. Bread delivered door to door by buses that patrol localities, } \\
\text { escorted by police officers to deter crowding. } 106 \text { NAF beneficiaries will receive the } \\
\text { bread for free with the support from municipalities. } \\
\text { The Social Security Corporation (SSC) will provide in-kind support to about 100,000 } \\
\text { (other reports indicate } 35,000 \text { - 50,000) vulnerable families that include an individual } \\
\text { over the age of } 70 \text { and casual workers. Food parcels have a monetary value of } \\
\text { JD40-50. The program may be extended to persons with chronic illnesses. SSC is also } \\
\text { studying to expanding the list to include families whose breadwinners have lost their } \\
\text { work, especially those working in the informal sector, in case the government } \\
\text { decided to extend the suspension } 108 \text {. }\end{array}$ \\
\hline Malaysia & $\begin{array}{l}\text { The Government will allocate RM } 25 \text { million (around US\$6 million) to be channeled } \\
\text { to vulnerable groups including the elderly and children in shelters, the disabled, and } \\
\text { the homeless. The Government will work with NGOs and social entrepreneurs to } \\
\text { distribute food, medical care equipment and shelter. }\end{array}$ \\
\hline
\end{tabular}




\section{Continued}

Food assistance package to be distributed to informal sector laborers and those in

Nepal need of assistance (including those living in old age homes, places of worship etc.) through ward committees at local level. To be funded by local and provincial level governments with top-ups from federal as required.

Source: Gentilini, Almenfi, and Dale (2020).

Table 6. Unemployment benefit.

\begin{tabular}{|c|c|}
\hline Country & Descriptive Summary \\
\hline Belgium & $\begin{array}{l}\text { Temporary unemployment available and the associated benefits are increased } 65 \% \\
\text { - } 70 \% \text { (the ceiling being set at } € 2754.76 \text { per month). Temporary unemployment } \\
\text { due to Coronavirus (force majeure) will be extended by } 3 \text { months (till June } 30 \text {, } \\
2020 \text { ). In addition to the unemployment benefit, workers get an extra } € 5.63 \text { per } \\
\text { day. A professional withholding tax of } 26.75 \% \text { will be deducted from this } \\
\text { compensation. }\end{array}$ \\
\hline Finland & $\begin{array}{l}\text { Workers laid off can claim income-linked benefits, provided they are a member of } \\
\text { an unemployment fund through their trade union or independently. } \\
\text { In addition, the government will eliminate the waiting period before people can } \\
\text { claim unemployment benefits, and allow freelancers and sole traders to claim } \\
\text { unemployment benefits without shutting down their businesses } 68 \text {. }\end{array}$ \\
\hline France & $\begin{array}{l}\text { Special unemployment benefits for employees who stop working. The company } \\
\text { compensates } 70 \% \text { of gross wages (about } 84 \% \text { of net). Minimum wage earners or } \\
\text { less are compensated } 100 \% \text {. The company will be fully reimbursed by the state for } \\
\text { those earning up to } 6927 \text { euros gross monthly-that is, } 4.5 \mathrm{x} \text { minimum wage } 71 \text {. }\end{array}$ \\
\hline $\begin{array}{l}\text { St Kitts and } \\
\text { Nevis }\end{array}$ & $\begin{array}{l}\text { Planned injection of EC\$12 million ( } \$ 4.44 \text { million) into the Severance Payments } \\
\text { Fund. }\end{array}$ \\
\hline Norway & $\begin{array}{l}\text { The rate of unemployment benefit for people who are laid off and for those who } \\
\text { lose their jobs has been raised to } 80 \% \text { of their income for an income of up to NOK } \\
300,000(\$ 28,350) \text { and } 62.4 \% \text { of income between NOK } 300,000 \text { and NOK } 600,000 \text {. } \\
\text { The Norwegian government is currently discussing whether to pay unemployment } \\
\text { benefits in advance. Thus, those who have lost their income will be able to get } \\
\text { money into their account quickly, without having to wait for processing of the } \\
\text { unemployment benefit application. }\end{array}$ \\
\hline
\end{tabular}

Source: Gentilini, Almenfi, and Dale (2020).

The African experience has also seen its share with most of its contributions being towards utility and financial obligations support (waiver/postponement). Botswana's insurance holders with AON Insurance had April 2020 non-payments by the insured written off with a hope of resuming premiums in May 2020. Table 7 shows Africa's contributions in light of COVID-19.

\section{Methodology}

Both literature review and empirical research were carried out in this study. Literature on the COVID-19 debate, with journal articles as new as for March and April 2020, is abundant and readily available. Researchers worldwide are churning out COVID-19 events as they unfold: per minute, per hour, per day, per week and per month. Reporting mostly on the number of infections, recoveries and deaths by province, country, and continent as well as giving detailed summaries 
Table 7. Africa's contribution towards COVID-19.

\begin{tabular}{|c|c|}
\hline Country & Descriptive Summary \\
\hline Algeria & $\begin{array}{l}\text { Cash transfers (admin/delivery adaptation), In-kind } \\
\text { food/voucher }\end{array}$ \\
\hline $\begin{array}{l}\text { Benin, Burkina Faso, Cote d'Ivoire, } \\
\text { Ghana, Guinea Bissau, Mali, Niger, } \\
\text { Senegal, Togo, Kenya }\end{array}$ & $\begin{array}{l}\text { Utility and financial obligation support } \\
\text { (waiver/postponement) }\end{array}$ \\
\hline Cape Verde & $\begin{array}{l}\text { Expansion of existing cash transfers program, Cash transfers, } \\
\text { In kind food support, School feeding, Utility and financial } \\
\text { obligation support (waiver/postponement), Wage subsidies }\end{array}$ \\
\hline Egypt & Cash transfers, Cash transfers \\
\hline Liberia & School feeding (take-home adjustment) \\
\hline Morocco & $\begin{array}{l}\text { Cash Transfer, Unemployment benefit, Social security } \\
\text { contribution Waiver/subsidy }\end{array}$ \\
\hline Namibia & $\begin{array}{l}\text { One-off cash grant, Utility and financial obligations } \\
\text { waivers/subsidies }\end{array}$ \\
\hline RSA & Cash Transfer, Paid sick leave, Unemployment insurance \\
\hline Tunisia & $\begin{array}{l}\text { Cash Transfer, Unemployment benefit, Healthcare insurance, } \\
\text { Social security contributions (waiver/subsidy) }\end{array}$ \\
\hline Uganda & Social security contributions subsidy/waiver \\
\hline
\end{tabular}

Source: Gentilini, Almenfi, and Dale (2020).

for the entire world, researchers are also reporting on initiatives by different nations.

Empirically, this research used an online questionnaire which was sent to 946 respondents via email. These potential providers of data are employed in various sectors of the economy of Botswana including, Mining, Manufacturing, Tourism, Agriculture and Tourism, among others.

\section{Questionnaire Sections}

Through reading the COVID-19 literature and the fast unfolding events in the world on television, radio, newspapers and other sources, the common thread that formed the basis of the questionnaire dealt with challenges being felt as a result of the pandemic. These included jobs losses, revenue reductions, and change in working styles, pay cuts and countries' responses towards alleviating the suffering of their populations. The situation in Botswana was not different from those in many other countries across the globe.

The first question solicited for sectors in which the respondent worked in (mining, tourism and others). The next four questions asked respondents to state the number of employees existing in their organisation before the pandemic, employees lost, the revenue and salary cuts as a result of the pandemic. The open ended questions allowed respondents to freely answer the following questions:

1) What do you think your company should do differently to keep your business? 
2) What are your company's envisaged marketing strategies to ensure continuity?

3) List some opportunities that your company envisages as a result of COVID-19?

In hindsight, it was reasonable to assume that the likelihood of getting valid and useful responses from such a huge number of participants (946) was high.

The main goal of this study is to assess the possibilities available after COVID-19.

\section{The survey}

To ensure consistency in future or repeated experiments, testing for reliability and content validity of the measurement scale is a critical step. Reliability and validity analysis, two methods consistent with various other studies (Chowdhury et al., 2007: p. 5; Kuo et al., 2009; Sakthivel \& Raju, 2006: p. 918; Hung et al., 2010: p. 430; Zadry \& Yusof, 2006: p. 1003), were used before finally using the questionnaire.

A two-stage survey method was used for this study. First, a pilot study was carried out in order to test the validity and reliability of the questionnaire. For the pilot study, the questionnaire was sent to ten (10) known respondents who work in different sectors. Question 1 asked for the economic sector of the respondent while question 2 needed respondents to state the number of workers in their company. When their answers came back, it was evident that the two questions needed to be given values for respondents to simple choose an option. For example the ten answers in question 1 resulted in ten different sectors which, when grouped, produced only three. For question 2, the number of workers per company was given as shown in Table 8.

With this varying random response style, it was found fitting to group these numbers into classes as depicted in Table 9.

Clearly, it can be seen that it is easier to group the number of workers and carry out the analysis based on frequencies rather than using ungrouped data. It is possible that one hundred respondents can produce 100 different numbers of employees which is tedious.

\section{FINDINGS}

This paper aimed to report on available possibilities in the economy and life of people in general after the peak of COVID-19.

An online survey involving revealed that the services sector had the most (33) respondents out of the 73 who participated. The manufacturing sector had 3 only. Figure 2 depicts a summary of all the sectors.

Participants were further asked: How many employees were there in your organization before COVID-19?

Some ranges were provided: 1 - 20, 21 - 40, 41 - 60 and so on. The results are depicted in Figure 3 with 18 respondents stating that their companies had between 81 and 100 while 16 said that their companies had more than 100. Follow-up questions revealed that those companies with more than 100 employees each were actually Government Departments and Ministries. 
Table 8. Pilot study results for question 1.

\begin{tabular}{ccccccccccc}
\hline Respondent & 1 & 2 & 3 & 4 & 5 & 6 & 7 & 8 & 9 & 10 \\
\hline Number of workers & 15 & 200 & 315 & 25 & 48 & 35 & 55 & 70 & 82 & 410 \\
\hline
\end{tabular}

Table 9. Number of Workers grouped in classes.

\begin{tabular}{cc}
\hline Number of workers & Frequency \\
\hline $1-20$ & 1 \\
$21-40$ & 2 \\
$41-60$ & 2 \\
$61-80$ & 1 \\
$81-100$ & 1 \\
Greater than 100 & 3 \\
Total & 10 \\
\hline
\end{tabular}

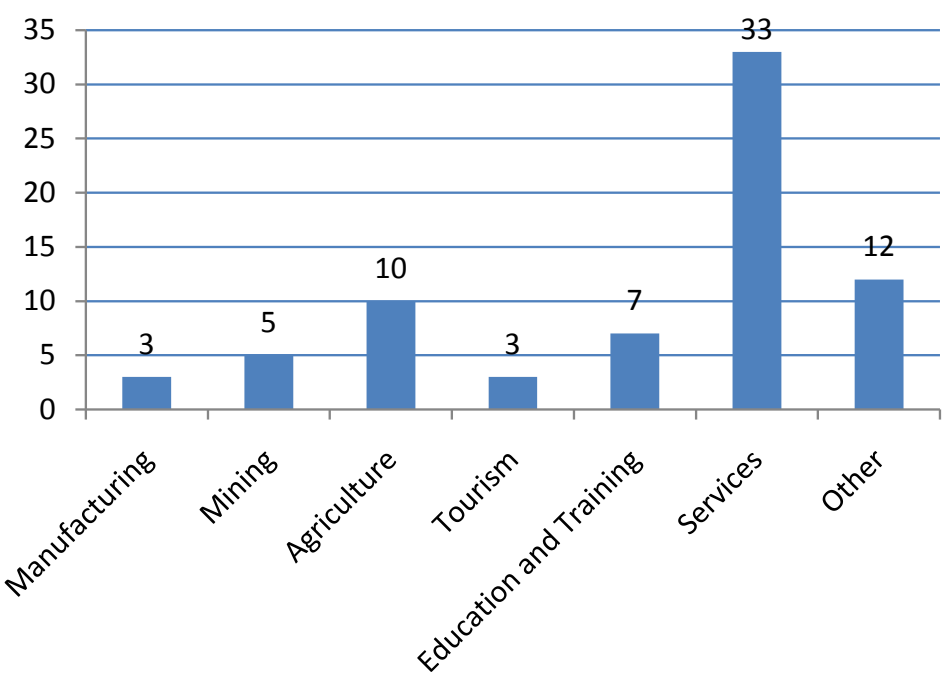

Figure 2. Participating sectors.

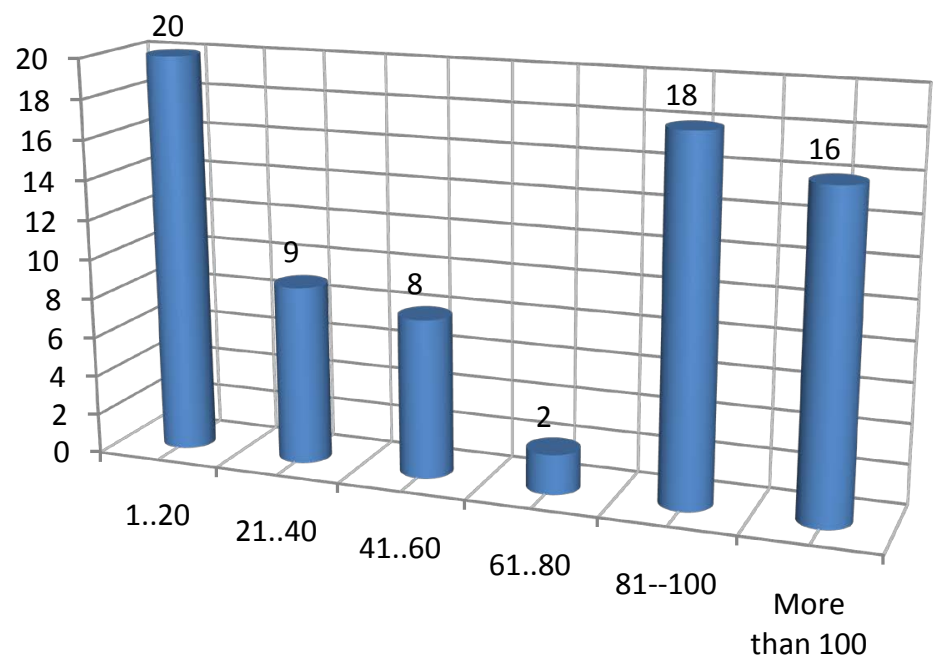

Figure 3. Employees in organizations before COVID-19. 
COVID-19 has had a negative effect on jobs. To this effect, a question was asked: "What \% of employees has your company lost (will your company lose) as a result of COVID-19?"

From Figure 4, 66 respondents indicated that job losses were less than $60 \%$. Among the respondents who participated in this research, no company laid off workers.

Regarding the loss of customers, respondents were asked: What \% of customers has your company lost (will your company lose) as a result of COVID-19? The results are depicted in Figure 5.

From Figure 5, respondents indicated the percentage losses varying between 0 and 100. 54 out of the 73 respondents stated that their companies had lost between $0 \%$ and $20 \%$ of their customers. The other representations were not significant with 6 reporting customer base reductions of between $21 \%$ and $40 \%$ (6 respondents), $41 \%$ and $60 \%$ (6 respondents), $61 \%$ and $80 \%$ (3 respondents) and between $81 \%$ and $100 \%$ ( 4 respondents).

Further, respondents were asked to approximate the percentage loss in sales revenue they felt their organizations experienced during lockdown. The results are depicted in Figure 6.

Figure 6 shows that 49 out of 73 respondents felt that the loss of revenue in their organisations was less than $60 \%$ of the normal while 15 indicated a loss between $60 \%$ and 79\%. 5 felt that they had lost between $80 \%$ and $99 \%$ and 4 indicated that they had lost all sales. These four who felt that they had lost all revenue indicated that, because of the lockdown, their manufacturing processes had been halted leading to no sales due to lack of products.

COVID-19 effects touched heavily of salaries. To this effect, respondents were asked the question: "What \% cut of salary did employees experience during lockdown?" The results are summarized in Figure 7.

In Figure 7, it is seen that most (34) reported a zero percent salary cut in their organisations. 5 stated that salaries were cut by $25 \%$ while 7 indicated that the

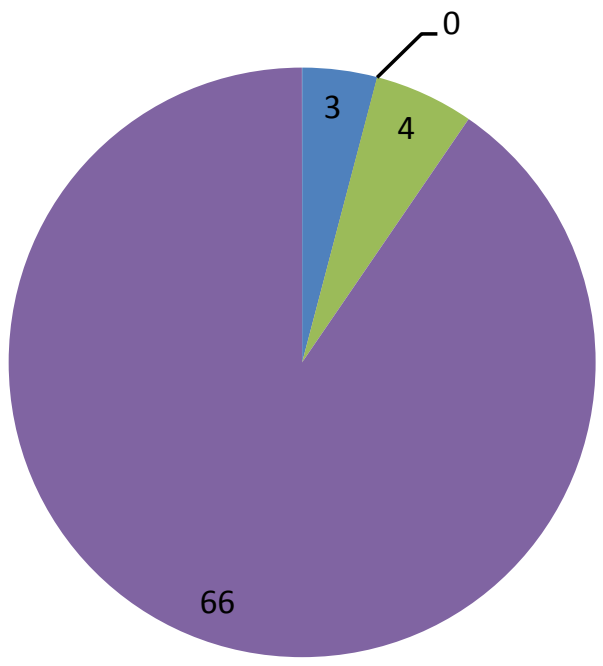

$100 \%$ jobs lost (all)

$80 \%-99 \%$

60\%-79\%

- Less than $60 \%$

Figure 4. Jobs lost due to COVID-19. 


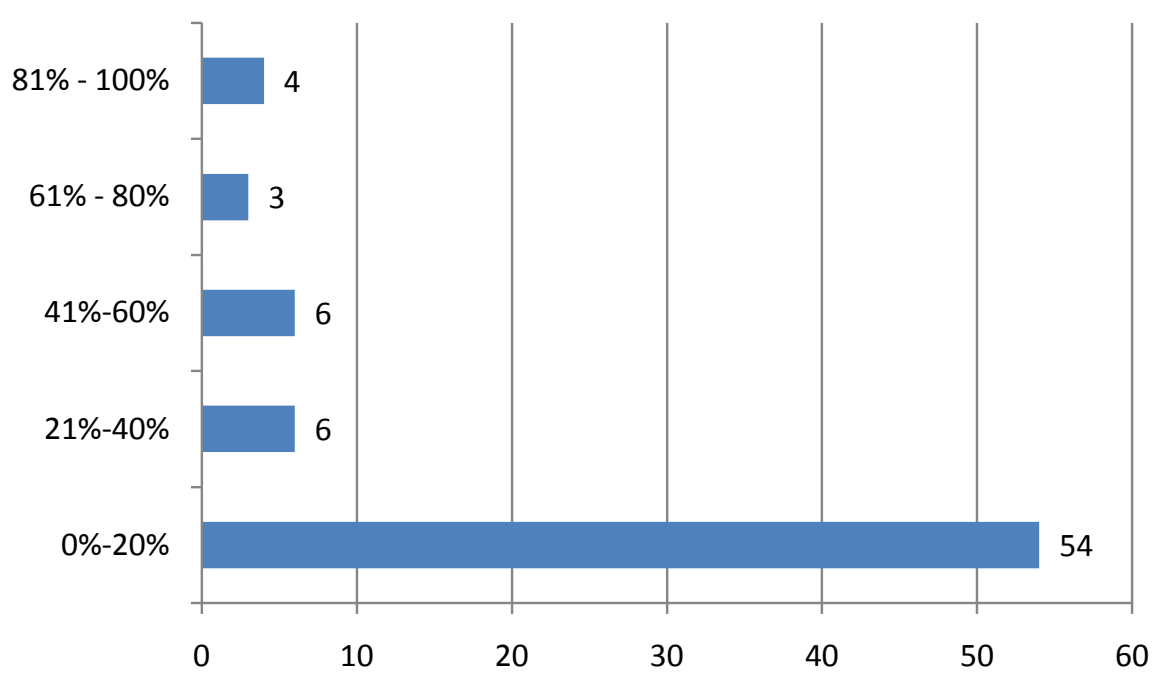

Figure 5. Customers lost due to COVID-19.

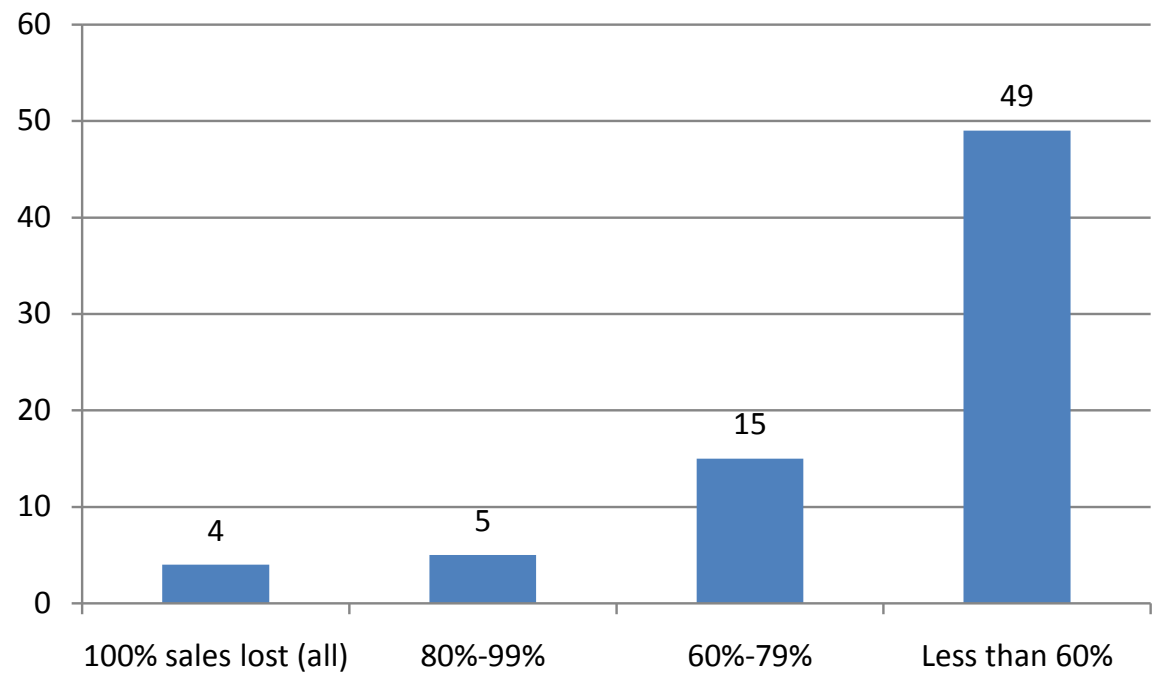

Figure 6. Sales revenue lostduring lockdown.

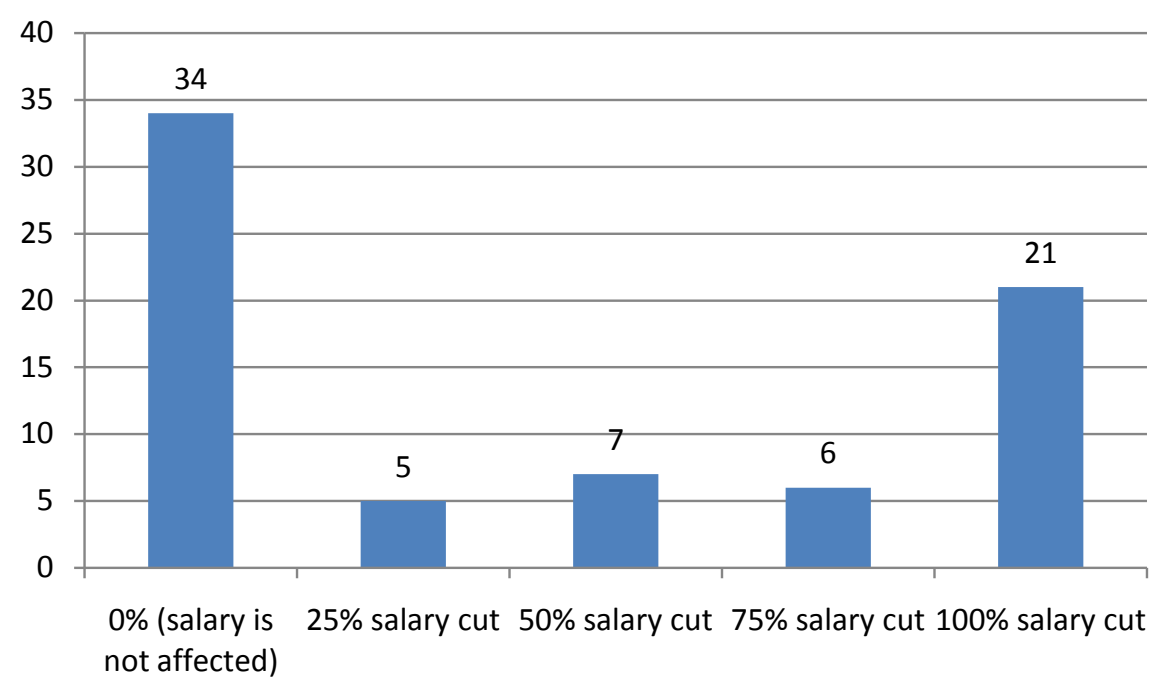

Figure 7. Salary cuts during lockdown. 
reductions in their organisations were 75\%. 21 indicated that salaries were stopped completely as company owners failed to raise enough income to pay workers.

\section{Themes}

The last three questions were open ended allowing the respondents to write whatever they wanted. The questions are:

1) What do you think your company should do differently to keep your business?

2) What are your company's envisaged marketing strategies to ensure continuity?

3) List some opportunities that your company envisages as a result of COVID-19?

The answers to these questions produced many varied answers but with common themes. The analysis of the findings now follows.

Respondents were asked the question on what their companies would start doing differently to ensure the business survived after COVID-19. Table 10 summarizes the findings.

This question produced 15 themes. From Table 10, an increased implementation of Internet based technology is what most (17\% or $23 \%)$ respondents said companies should do differently in order for businesses to survive. This was followed by those who indicated that COVID-19 health protocols (10\% or 14\%) had to be strictly followed as well as a group of (10\% or 14\%) who stated that they were from Government and had no suggestions.

Table 10. What do you think your company should do differently to keep your business?

\begin{tabular}{|c|c|c|c|}
\hline$\#$ & Theme & Number & $\%$ \\
\hline 1 & Advanced Planning & 2 & 3 \\
\hline 2 & Aggressive Marketing & 8 & 11 \\
\hline 3 & COVID19 health protocols & 10 & 14 \\
\hline 4 & Diversification & 5 & 7 \\
\hline 5 & Increase production & 2 & 3 \\
\hline 6 & Internet based technology & 17 & 23 \\
\hline 7 & Layoff some workers & 2 & 3 \\
\hline 8 & Get a loan & 1 & 1 \\
\hline 9 & Localize labor and innovate & 3 & 4 \\
\hline 10 & Motivate and retain & 3 & 4 \\
\hline 11 & Non-Profit Organization & 1 & 1 \\
\hline 12 & Reduce prices, charge nominal fees & 6 & 8 \\
\hline 13 & Shift work & 2 & 3 \\
\hline 14 & Training and Development & 1 & 1 \\
\hline \multirow[t]{2}{*}{15} & We are Government, Nothing & 10 & 14 \\
\hline & Total & 73 & 100 \\
\hline
\end{tabular}


Regarding envisaged marketing strategies to ensure business continuity, a large number of the respondents (32\% or $44 \%)$ stated that their companies had to embark on an aggressive marketing campaign supported by huge budgets. The rest of the reactions are shown using Table 11.

Further, respondents were asked if they foresaw any opportunities as a result of COVID-19 that their companies may take. Table 12 summarizes the responses.

From Table 12, it can be seen that the new normal where information technology, hygiene, social distancing and flexi-hours are the opportunities that companies have realized can be taken up. 29 out of 73 respondents (40\%) indicated the need to adapt the new normal concept so as to change the way they operated in their businesses. Unfortunately, a sizeable number (21) did not realize any opportunities.

Table 11. What are your company's envisaged marketing strategies to ensure continuity?

\begin{tabular}{cccc}
\hline$\#$ & Theme & Number & $\%$ \\
\hline 1 & Aggressive Marketing & 32 & 44 \\
2 & COVID19 health protocols & 4 & 5 \\
3 & Increase production & 1 & 1 \\
4 & Internet based technology & 8 & 11 \\
5 & Motivation and retention of workers & 9 & 12 \\
6 & Non-Profit Organization & 1 & 1 \\
7 & Reduce prices, charge nominal fees & 4 & 5 \\
8 & Revision of calendar & 1 & 1 \\
9 & Risk Management & 1 & 1 \\
10 & Shift work & 1 & 1 \\
11 & Supplier & 1 & 1 \\
12 & We are Government, Nothing & 10 & 14 \\
& Total & 73 & 100 \\
\hline
\end{tabular}

Table 12. List some opportunities that your company envisages as a result of COVID-19?

\begin{tabular}{cccc}
\hline$\#$ & Themes & Number & $\%$ \\
\hline 1 & Government subsidy helps & 2 & 3 \\
2 & Increased marketing drive & 1 & 1 \\
3 & Localize Labor & 6 & 8 \\
4 & New Business opportunities & 8 & 11 \\
5 & New Normal: ICT, Hygiene. Social Distancing, Flexi Hours & 29 & 40 \\
6 & No opportunities & 21 & 29 \\
7 & Revise insurance cover & 3 & 4 \\
8 & Tourism boost & 3 & 4 \\
& Total & 73 & 100
\end{tabular}




\section{Discussion of Findings}

The results obtained tally in many ways with those found in literature. The COVID-19 pandemic effects are fast unfolding and reports of sales losses, job cuts, salary reductions and the advent of the "new normal" are widely debated. This study had 73 participants only who reported on their organisations. The literature is addressing the whole world and in all reports showing the same trend seen from the study.

The study found out that job cuts were a common feature in many organisations. The International Labor Organization (2020) is keeping track of job losses and has already predicted that about 2.7 billion workers worldwide will lose their jobs citing SMEs as the major challenged group.

Perhaps the most intriguing finding is the change in which people and organizations are now adapting to changing engagement behaviors in which they maintain social distancing and work from home most of the time. In just this small part of the globe, many employers are working from the comfort of their homes to, among others; deliver lectures to students in remote sites, hold meetings and to attend churches. Literature unfolding so far is abundant in this aspect. UNESCO (2020) has predicted an increase of $261 \%$ in working online. Bouey (2020) and Shetty (2020) emphasize the need to work from home. Lin (2020) observed China's engagement online noting the emptiness of streets except for those who deliver food and other amenities. Bao (2020) note that Perking University is already offering 1824 postgraduate courses online. On the other hand, Shrivastava (2020) noting that technology startups will cut more jobs in retail, hospitality, mobility and financial services.

More results are still unfolding with all literature pegged at year 2020.

\section{Conflicts of Interest}

The authors declare no conflicts of interest regarding the publication of this paper.

\section{References}

2020 Global Economic Prospects Report.

Arunmas, P. (2020). Businesses Urge Relaxing Lockdown to Stem Job Losses.

Bao, W. (2020). COVID-19 and Online Teaching in Higher Education: A Case Study of Peking University. Human Behavior and Emerging Technologies, 2, 113-115. https://doi.org/10.1002/hbe2.191

Bouey, J. (2020). Assessment of COVID 19's Impact on Small and Medium Sized Enterprises. Implications from China. CT-524. Testimony Presented before the House Small Business Committee on March 10, 2020. https://doi.org/10.7249/CT524

Chowdhury, M., Paul, H., \& Das, A. (2007). The Impact of Top Management Commitment on Total Quality Management Practice: An Exploratory Study in the Thai Garment Industry. Global Journal of Flexible Systems Management, 8, 17-29. https://doi.org/10.1007/BF03396517

Gentilini, U., Almenfi, M., \& Dale, P. (2020). Social Protection and Jobs Responses to 
COVID-19: A Real-Time Review of Country Measures. Living Paper, World Bank.

Hung, R. Y., Lien, B. Y., Fang, S., \& McLean, G. N. (2010). Knowledge as a Facilitator for Enhancing Innovation Performance through Total Quality Management. Total Quality Management, 21, 425-438. https://doi.org/10.1080/14783361003606795

International Labor Organization, ILO (2020). ILO Monitor: COVID-19 and the World of Work (2nd ed.). Updates Estimates and Analysis.

Kar, S. (2020). Software Engineers \& Sales Staff Most Affected by Layoffs at Startups.

Kuo, T., Chang, T., Hung, K., \& Lin, M. (2009). Employees' Perspective on the Effectiveness of the ISO 9000 Certification: A Total Quality Management Framework. Total Quality Management, 20, 1321-1335. https://doi.org/10.1080/14783360903250530

Lin, C. (2020). Delivery Technology Is Keeping Chinese Cities Afloat through Coronavirus.

Nayar, L., Sood, J., Kansara, Y., \& Ahmad, S. (2020). Is Your Job Safe?

Sakthivel, P. B., \& Raju, R. (2006). Conceptualizing Total Quality Management in Engineering Education and Developing a TQM Educational Excellence Model. Total Quality Management, 17, 913-934. https://doi.org/10.1080/14783360600595476

Shetty, S. (2020). Safety Tips for Digital Transactions during a Lockdown. The World Bank East Asia and Pacific Economic Update. East Asia and Pacific in the Time of COVID 19.

Shrivastava, A. (2020). Paycut, Layoffs: Startup Morale under Lockdown.

The World Bank (2020).

UNESCO (2020). COVID-19 Educational Disruption and Response. https://en.unesco.org/covid19/educationresponse

United Nations (2020). From the Great Lockdown to the Great Meltdown. Developing Country Debt in the Time of Covid-19.

World Health Organization, WHO (2020).

Zadry, H. R., \& Yusof, A. M. (2006). Total Quality Management and Theory of Constraints Implementation in Malaysian Automotive Suppliers: A Survey Result. Total Quality Management, 17, 999-1020. https://doi.org/10.1080/14783360600747911 